\title{
ERRATUM
}

\section{Disrupted hippocampal neuregulin-1/ErbB3 signaling and dentate gyrus granule cell alterations in suicide}

I Mahar, B Labonte, S Yogendran, E Isingrini, L Perret, MA Davoli, A Rachalski, B Giros, G Turecki and N Mechawar

Translational Psychiatry (2017) 7, e1243; doi:10.1038/tp.2017.214; published online 26 September 2017

Correction to: Translational Psychiatry (2017) 7, e1161; doi:10. 1038/tp.2017.132; published online 4 July 2017

As a result of a technical error on the part of the publisher, certain corrections to the article requested by the authors at the

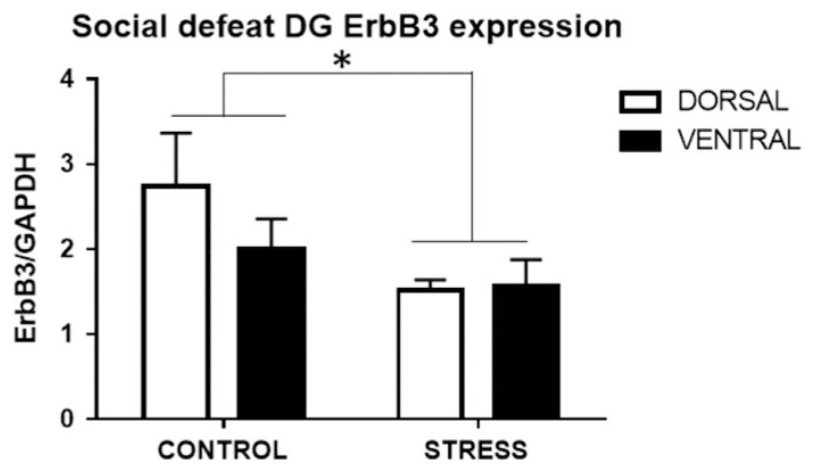

Figure 3. Chronic social defeat stress reduces ErbB3 expression in the dentate gyrus (DG). ${ }^{*} P<0.05$ (main effect of experimental condition for stressed vs control animals). proofing stage were not made prior to publication, which could potentially lead to confusion to the reader. The authors emphasize that these errors do not affect the nature of the results described, merely their presentation in the article. The revised version of Figure 3 and its legend appear here. The legends that should have accompanied the original Supplementary Table and Supplementary Figures are available as online with this erratum. The publisher regrets the errors.

This work is licensed under a Creative Commons Attribution-
NonCommercial-NoDerivs 4.0 International License. The images or
other third party material in this article are included in the article's Creative Commons
license, unless indicated otherwise in the credit line; if the material is not included under
the Creative Commons license, users will need to obtain permission from the license
holder to reproduce the material. To view a copy of this license, visit http://
creativecommons.org/licenses/by-nc-nd/4.0/
(c) The Author(s) 2017

